\title{
Cyclic and Acyclic Azaperoxides
}

\author{
Nataliya N Makhmudiyarova* and Askhat G Ibragimov \\ Institute of Petrochemistry and Catalysis of Russian Academy of Sciences, Russia
}

*Corresponding author: Nataliya N Makhmudiyarova, Institute of Petrochemistry and Catalysis of Russian Academy of Sciences, Russia

ARTICLE INFO

Received: 幽 August 08, 2019

Published: September 06, 2019

Citation: Nataliya N Makhmudiyarova, Askhat G Ibragimov. Cyclic and Acyclic Azaperoxides. Biomed J Sci \& Tech Res 21(2)-2019. BJSTR. MS.ID.003561.

\section{ABSTRACT}

The review integrates and systematically describes the data on the synthesis of three-, four-, five-, six-, and eight-membered cyclic and acyclic amino-peroxides.

Keywords: Aza-Peroxide Compounds; Dioxaziridines; Dioxazetidines; Dioxazetes; Dioxadiazetidines; 1,2,4-Dioxazolidine; Dioxatetrahydropyridazines; Endoperoxides; Ozonolysis; Tetraoxazaspiroalkanes; Tetraoxazaspiroalkanes; Acyclic Aminodiperoxides; Catalysis

\section{Introduction}

The enhanced interest in organic peroxide compounds is caused by their broad scope of applications, first of all, in chemical and pharmaceutical industry and in laboratory practice. A real breakthrough in the synthesis of peroxide compounds was made after the discovery of the antimalarial activity of peroxides, which is utilized in highly efficient medicinal drugs (artemisinin, artesunate, artemether, dihydroartemisinin). The advances in the peroxide chemistry and pharmacology stimulated the research related to the synthesis of heteroatom-containing peroxides. Out of heteroatomcontaining peroxides, attention of researchers is focused on aminoperoxides. This enhanced interest in aza-peroxides is attributable to the fact that many natural compounds (verruculogen, dioxetanone) and antimalarial agents (RKA182 and OZ439) contain aza-peroxy moieties in the molecules. The extensive biological activity of nitrogen-containing peroxides promoted active research on the development of synthetic routes to new classes of acyclic and cyclic amino-peroxides.

It is noteworthy that a compound containing both a nitrogen atom and a peroxide group in the molecule was first mentioned in the world literature back 1900 [1]. Despite more than a 100year history, amino-peroxides remain poorly studied because of complicated synthesis and small number of available preparation methods. In view of the high practical significance of fundamental and applied research dealing with the synthesis and use of amino- peroxides and extensive interest of researchers in this promising and intriguing field of chemistry, in the present review, we attempted to give a critical account of the achievements of both foreign and Russian researchers engaged in the synthesis and studies of the properties of three-, four-, five-, six-, and eight-membered cyclic and acyclic amino-peroxides with the goal of integrating published results.

\section{Three-Membered Aza-Peroxides}

The simplest cyclic peroxide derivatives are composed of a 3-membered ring consisting of one nitrogen and two oxygen atoms. These dioxaziridine rings can be formed both from nitro compounds [RN (O) O] and from nitroso O-oxides (RNOO) (Scheme 1). Dioxaziridines 1 (aza-dioxiranes) have not been isolated in a pure state, but have been identified as unstable intermediates in solutions in 2-methyltetrahydrofuran at $77 \mathrm{~K}$ [2] or acetonitrile at 298 K [3].

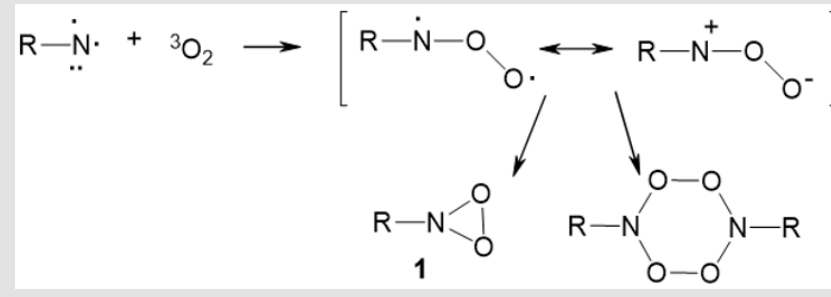

Scheme 1: Reaction of nitrene with $\mathrm{O}_{2}$. 
Dioxaziridines are unstable at room temperature. Most often, they are detected by UV spectroscopy. The key methods used to generate dioxaziridines are photooxidation of aryl azides and

0-substituted diazeniumdiolates according to Scheme 1. The main representatives of dioxaziridines and methods for their generation are summarized in Table 1.

Table 1: Generation of dioxaziridines 1 (RNO2 dioxiranes).

\begin{tabular}{|c|c|c|c|c|c|}
\hline Year & Structure & Evidence for the formation & $\mathrm{T}(\mathrm{K})$ & Generation method & Refs \\
\hline 2004 & $\mathrm{Ph}-\mathrm{N}^{\prime}$ & Luminescence data & 298 & A & {$[4,5]$} \\
\hline 2002 & $\mathrm{~N}_{3}-\mathrm{C}_{6} \mathrm{H}_{4}-\mathrm{C}_{6} \mathrm{H}_{4}$ & Luminescence data & 298 & $\mathrm{C}$ & [6] \\
\hline 2001 & $\mathrm{PhCH}_{2} \mathrm{O}$ & Kinetic measurements & 298 & $\mathrm{D}$ & [7] \\
\hline 2001 & $\mathrm{~N}_{3}-\mathrm{C}_{6} \mathrm{H}_{4}-\mathrm{C}$ & Luminescence data & 293 & A & [8] \\
\hline 1996 & $\begin{array}{l}\mathrm{Ar}=p-\mathrm{MeOC}_{6} \mathrm{H}_{4} \\
\mathrm{Ph}, p-\mathrm{NO}_{2} \mathrm{C}_{6} \mathrm{H}_{4}\end{array}$ & ${ }^{18} \mathrm{O}_{2}$ marker & 298 & B & [2] \\
\hline 1991 & $\mathrm{Ph}-\mathrm{N}$ & ${ }^{18} \mathrm{O}_{2}$ marker & 298 & B & [9] \\
\hline 1987 & $\mathrm{Ph}-\mathrm{N}^{\prime}$ & ${ }^{18} \mathrm{O}_{2}$ marker & 298 & B & [10] \\
\hline
\end{tabular}

Note: A, Matrix isolation upon photooxidation of $\mathrm{ArN}_{3}$; B, photooxidation of $\mathrm{ArN}_{3}$ at room temperature in solution; C, substrates adsorbed on natural rubber; $\mathrm{D}$, photooxidation of diazoniumdiolate in solution at room temperature.

\section{Four-Membered Aza-Peroxides}

Four-membered aza-peroxides are represented by three types of compounds: dioxazetidines, dioxazetes, and dioxadiazetidines. 1,2-Dioxetanes 2 without nitrogen atom in the ring are among the most readily accessible four-membered peroxide heterocycles, which are synthesized by treatment of alkenes with singlet oxygen $[11,12]$. Adamantyl- and alkoxy-substituted 1,2-dioxetanes are most stable, whereas other derivatives easily decompose to carbonyl compounds [13]. A similar decomposition pathway should be expected for 1,2,3-dioxazetidines 3, which are generated upon the reaction of singlet oxygen with imines $[14,15]$. This reaction was first studied in relation to treatment of benzophenone oxime with singlet oxygen to give the oximate anion and 0-methyl ether 4 (Scheme 2) [16].<smiles>[R]C1([R])OOC1([R])C</smiles>

2<smiles>[R]N1OOC1([R])[R]</smiles>

3<smiles>[R]ON=C(c1ccccc1)c1ccccc1</smiles>

$$
\mathrm{R}=\mathrm{H}, \mathrm{CH}_{3}
$$

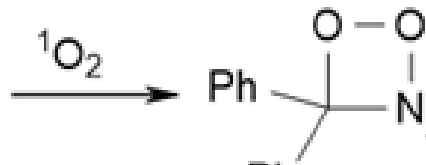

$\mathrm{Ph}$

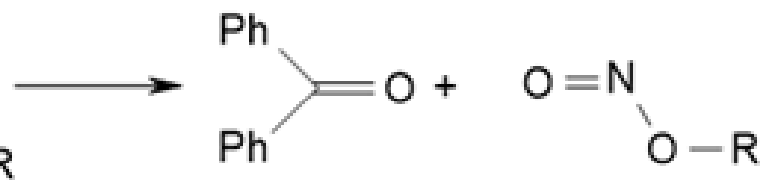

Scheme 2: Photooxidation of O-methyl ethers. 
However, $\mathrm{C}=\mathrm{N}$ containing compounds are not always able to be converted by this photooxidation mechanism. The photooxidation of acyclic ketoximes, aromatic aldoximes and ketoximes, and $\alpha$-oximino ketones yields the corresponding aldehydes resulting from the competing oxidation of the $\mathrm{C}=\mathrm{C}$ bond [17]. Amidoximes behave in a similar way, but in this case, the anionic species react with oxygen to give nitriles and amides (via intermediate acyclic peroxide derivatives) rather than 1,2,3-dioxazetidines [18]. Another reaction pathway to the intermediate formation of 1,2,3-dioxazetidine
5 involves, instead of singlet oxygen, UV-induced photooxidation of $\mathrm{N}$-methoxy-4-methoxyphenyl-4'-methylphenylmethanimine in the presence of 9,10-dicyanoanthracene as a photosensitizer (Scheme 3) $[19,20]$. The 1,2,3-dioxazetidine 5 thus formed decomposes to give diaryl ketone and methyl nitrite with photoisomerization of the $\mathrm{C}=\mathrm{N}$ double bond [19].

$$
\begin{array}{r}
\mathrm{O}-\mathrm{O} \\
\mathrm{i}-\mathrm{i} \\
\mathrm{R}-\mathrm{O}
\end{array}
$$

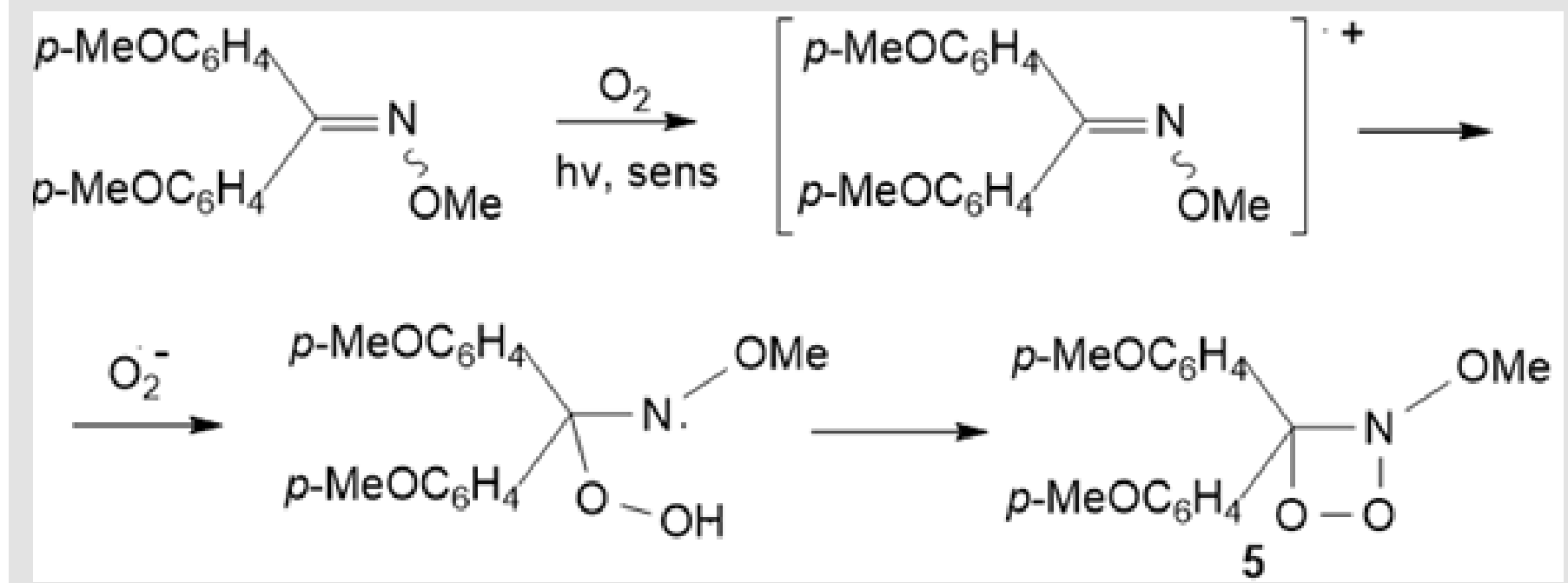

Scheme 3: UV photooxidation of N-methoxy-4-methoxyphenyl-4'-methylphenylmethanimine with the photosensitizer 9,10-dicyanoanthracene.

1,2,3-Dioxazetidine 6 is formed as an intermediate upon luminescence of acyl hydrazide based on 5-methyldehydroluciferin in the presence of a strong base (Scheme 4) [21]. Nitroso compounds such as $\mathrm{N}, \mathrm{N}$-dimethyl-4-nitrosoaniline possess bleaching properties owing to the reaction of singlet oxygen with imidazole or histidine [22], which involves the step of endoperoxide formation [23,24]. The authors assume the intermediate formation of trioxazetidine 7 upon the [2+2] -cycloaddition of nitroso groups.<smiles>COON(N)C(=O)c1csc(-c2nc3ccc(O)cc3s2)n1</smiles>

Scheme 4: Photooxidation of acylhydrazine. 
1,2,3,4-Dioxadiazetidines 8 are dimers of nitroso compounds. They are also products of $[2+2]$-cycloaddition of azo compounds and oxygen. Nevertheless, they have not yet been characterized. An example of intermediate formation of energetic 1,2,3,4-dioxadiazetidine 10 upon isomerization of benzofurazan 1-oxide (benzofuroxan) 9 has been reported [25] (Scheme 5).<smiles>[O-][n+]1onc2ccccc21</smiles>

9<smiles>CSc1cccc2c1n1oon21</smiles>

10

Scheme 5: Isomerization of benzofurazan 1-oxide.

\section{Five-Membered Aza-Peroxides}

Ozonolytic Methods for the Synthesis of Five-Membered Aza-Peroxides: The most efficient method for the preparation of cyclic aza-peroxides is the ozone oxidation of the olefinic bond in the presence of nitrogen-containing compounds. For instance, ozone treatment of vinyl ethers 12 in the presence of imines [26] leads to the [3+2]-cycloaddition of carbonyl oxides 11 generated upon ozonation to appropriate imines 13 to give 1,2,4-dioxazolidine five-membered ring 14 (Scheme 6).<smiles>[R6]N=C([R3])[R3]</smiles>

Scheme 6: Synthesis of 1,2,4-dioxazolidines by the ozonolysis of vinyl ethers in the presence of imines.

It is noteworthy that the reactivity of intermediate carbonyl oxide 11 in this reaction depends on the steric factors involved in its approach to the imine, which are normally determined by the carbonyl oxide structure. The reaction is stereoselective in most cases: out of the 26 compounds obtained by this method, only seven products were formed as isomer mixtures [26]. The ozone oxidation of indene $15 a-e$ and pyrene 17 derivatives in the presence of primary amines afforded bicyclic 1,2,4-dioxazolidines [27]. Treatment of a mixture of substituted indenes 15a-e and primary amines with ozone at $-70^{\circ} \mathrm{C}$ gave $1,2,4$-dioxazolidine derivatives 16a-e in high yields. Ozonolysis of pyrene 17 under similar conditions resulted in the synthesis of cyclic amino-peroxides 18a,b, but the conversion was low (Scheme 7). Various primary amines such as cyclohexylamine, benzylamine, aniline, and tertbutylamine can serve as the nitrogen cross-components. Unlike primary amines, secondary amines cannot be used in this reaction, as they are readily oxidized themselves.<smiles>[R]C1([R2])C=Cc2ccccc21</smiles><smiles>[R]OC1C2OC([R])([R])C1N1OC21</smiles>

a $R_{1}=R_{2}=H, R=t-B u, 90 \%$

b $R_{1}=t-B u, R_{2}=H, R=t-B u, 90 \%$

c $\mathrm{R}_{1}=\mathrm{R}_{2}=\mathrm{CH}_{3}, \mathrm{R}=t-\mathrm{Bu}, 80 \%$

d R $R_{1}=\mathrm{R}_{2}=\mathrm{CH}_{3}, \mathrm{R}=\mathrm{C}_{6} \mathrm{H}_{11}, 70 \%$

e $\mathrm{R}_{1}=\mathrm{C}_{4} \mathrm{H}_{7}, \mathrm{R}=t-\mathrm{Bu}, 90 \%$<smiles>CCOC(=O)CC(C)=O</smiles>

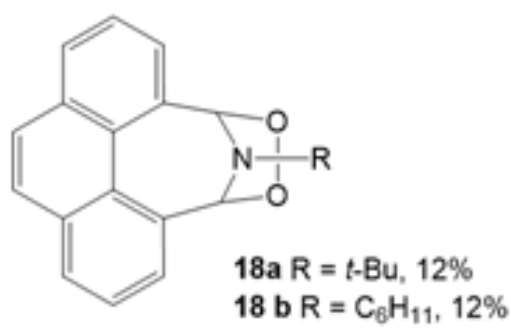

Scheme 7: Synthesis of 1.2.4-dioxazolidines derivatives by the ozonolysis of indenes in the presence primery amines. 
An efficient method for the formation of N-methoxy-substituted 1,2,4-dioxazolidine moiety is ozonolysis of dimethyldioximes of 1,4- and 1,5-diarbonyl compounds [28]. This one-step method is characterized by good conversion and stereoselectivity. While developing studies on ozonolysis of vinyl ethers in the presence of imines, K. Griesbaum and-co-workers investigated ozonolysis in the absence of carbonyl oxide acceptors. The reaction of dimethyldioximes 19a-e with ozone in an inert solvent afforded N-me- thoxy-1,2,4-dioxazolidine derivatives 20a-e (Scheme 8). Relying on these data, Kang-Ryul Lee and co-workers [29] accomplished ozonation of acyclic 0-methylated dioximes $19 \mathrm{f}-\mathrm{i}$ with $\mathrm{n}=4-6$ and aromatic 0-methylated dioximes $21 \mathrm{a}$ and $21 \mathrm{~b}$ (Scheme 9). Ozonolysis of $19 \mathrm{f}-\mathrm{i}$ in dichloromethane at $-78^{\circ} \mathrm{C}$ furnished the corresponding bicyclic 1,2,4-dioxazolidines 20f-i in 67, 59, 31, and 53\% yields, respectively.

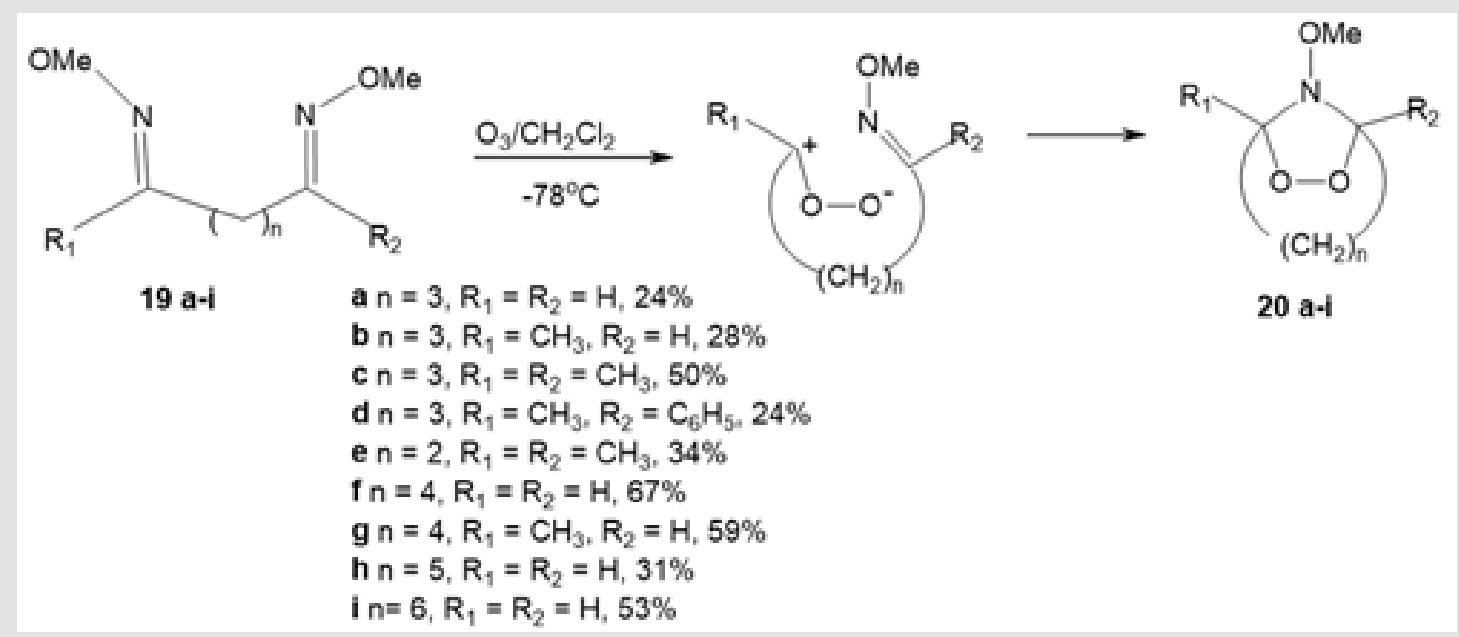

Scheme 8: Ozonolyses of the O-methylated dioximes.

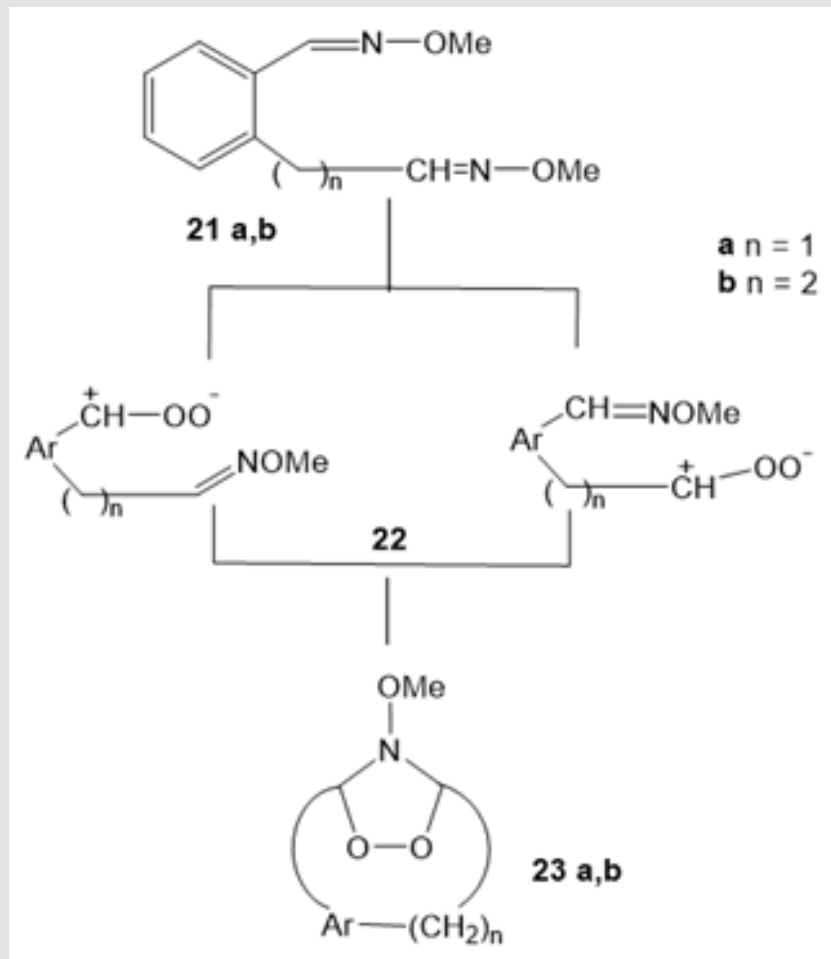

Scheme 9: Synthesis of O-methylated-1,2,4-dioxazolidines by ozonolyses of O-methylated dioximes.

The ozonolysis [29] of aromatic 0-methylated dioximes 21a and $21 \mathrm{~b}$ in dichloromethane at $-78^{\circ} \mathrm{C}$ gave rise to aromatic $1,2,4$-dioxazolidines 23a and 23b via intermediates 22 in 65 and 35\% yields. Yet another example of ozonolytic preparation of 1,2,4-dioxazolidines is ozonation of 1-decene 24 in a homogeneous system containing ammonia and water (Scheme 10) [30]. The amino-peroxide 25 thus formed was unstable and decomposed in air. 


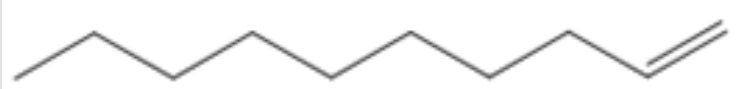

24

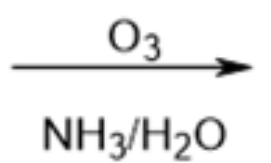

$\mathrm{NH}_{3} / \mathrm{H}_{2} \mathrm{O}$<smiles>[10BH2]C1NC([10BH2])OO1</smiles>

25

Scheme 10: Synthesis of 1,2,4-dioxazolidines.

The ozonation of 3-methyl-6-methoxy-2-phenylindole (2-phenylskatole) 26 leads to 2-phenylbenzoxazine hydroperoxide able to exist as two tautomers occurring in equilibrium, ozonide 27 and hydroperoxide 28 (Scheme 11) [31]. The first synthesis of triterpenoid amino-peroxide with 1,2,4-dioxazolidine moiety by ozonation of 3,5-seco-18 $\alpha$-oleane 3,5-bismethyl dioxime 29 in $\mathrm{CH}_{2} \mathrm{Cl}_{2}$ at $0^{\circ} \mathrm{C}$ has been discussed in the literature [32]. The reaction is stereoselective and gives only one (3S,5S)-diastereomer of 19ß,28-epoxy-A-neo-3,5-seco-3S,5S-dioxy-3,5-N-methoxyazo$18 \alpha$-oleane 30 (48\%). 19ß,28-Epoxy-28-oxo-A-neo-3,5-seco-3S,5Sdioxy-3,5-N-methoxyazo- $18 \alpha$-oleane 31 is formed as a side product in $11 \%$ yield (Scheme 12 ).<smiles>COc1ccc2c(C)c(C(=O)O)[nH]c2c1</smiles>

26

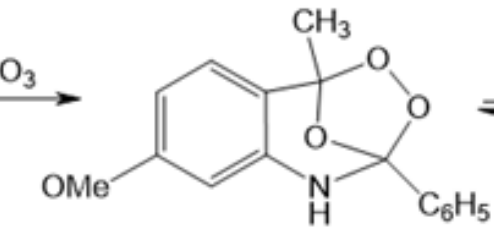

27<smiles>C=CCCCCCCCCCCCCO</smiles>

Scheme 11: The ozonation of 3-methyl-6-methoxy-2-phenylindole.

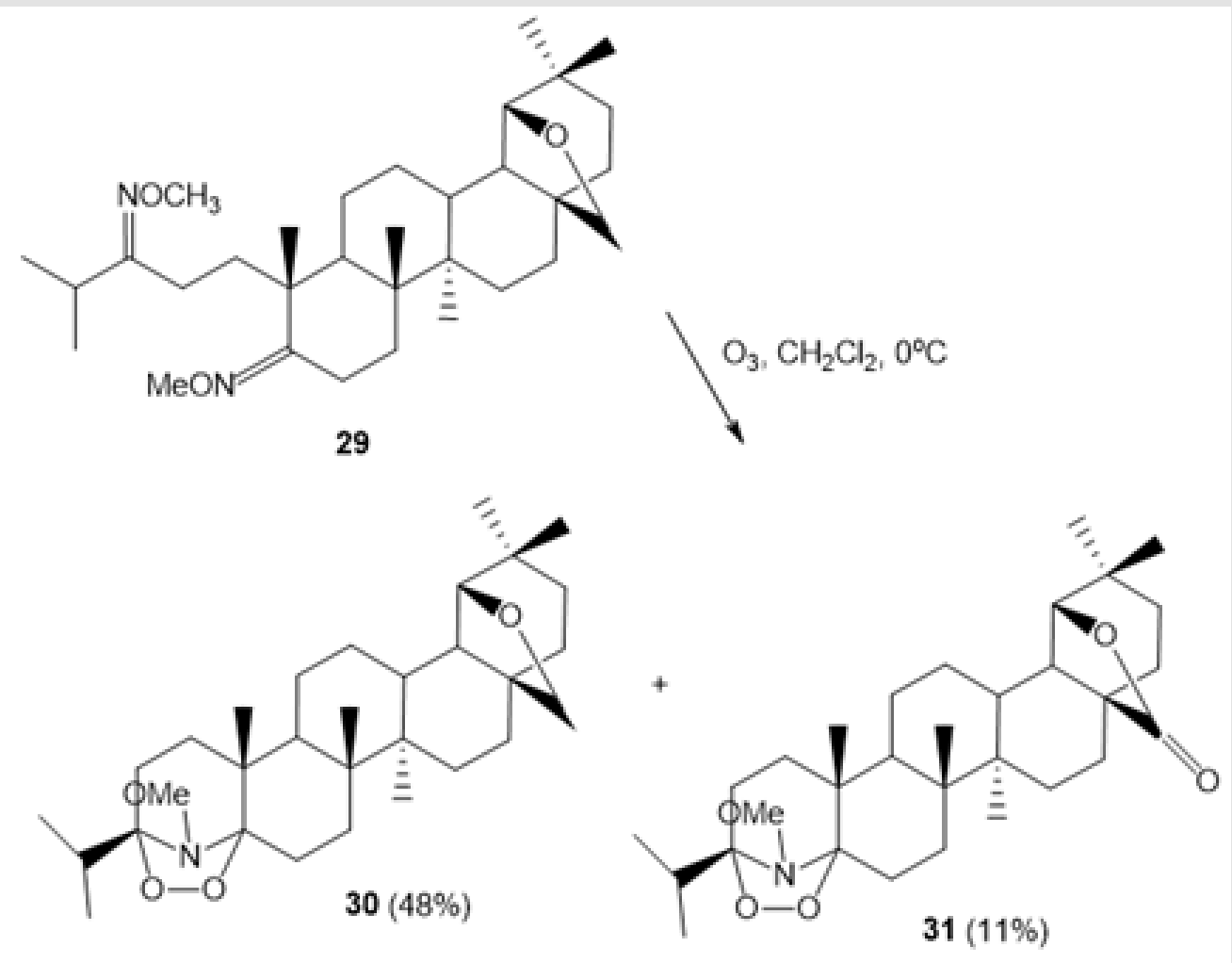

Scheme 12: Synthesis of triterpenoid-based 1,2,4-dioxazolidines by ozonolysis of allobetulin derivatives. 
Photochemical Methods for the Synthesis of FiveMembered Aza-Peroxides

1,2,4-Dioxazolidines can be prepared by photochemical oxidation with singlet oxygen. Using this approach, 1,2,4-dioxazolidines 33a-d were synthesized for the first time by photooxidation of aziridines 32a-d in dry acetonitrile in the presence of 9,10-dicyanoanthracene (Scheme 13) [33-35]. The reaction is stereoselective if no steric restrictions are present at the nitrogen atom. The stereochemistry of the reaction products does not depend on cis-/trans- positions of substituents at the neighboring carbon atoms in the starting compounds.<smiles>[R]N1C(P)C1[Hg]c1ccccc1</smiles>

32 a-d

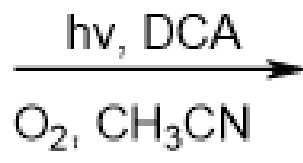

$\mathrm{Ph}$<smiles>[R]N1C([R])([PH])OOC1([2H])c1ccccc1</smiles>

33 a-d
a $\mathrm{R}=\mathrm{H}, 39 \%$, cis/trans 100:1
b $\mathrm{R}=\mathrm{C}_{2} \mathrm{H}_{5}, 40 \%$, cis/ trans $87: 13$
c $\mathrm{R}=n-\mathrm{Bu}, 33 \%$, cis/trans $87: 13$
d $\mathrm{R}=\mathrm{PhCH}_{2}, 40 \%$, cis/trans 40:60

Scheme 13: Formation 1,2,4-dioxazolidines by electron-transfer photooxygenation of aziridines.

The presumptive scheme of photochemical transformation of aziridines 32 into 1,2,4-dioxazolidines 33 includes aziridine ring opening under the action of singlet 9,10-dicyanoanthracene to give radical cations 34 and 35 in which the cis-configuration is the most stable. Then electron transfer takes place, resulting in azomethines 36 and 37, which undergo 1,3-dipolar cycloaddition with singlet oxygen to give 1,2,4-dioxazolidine compounds 33a-d (Scheme 14). If bulky substituents are present, cis-configuration of the intermediate radical cation 34 becomes unfavorable, which results in the formation of a mixture of cis- and trans- amino-peroxides. Therefore, the reaction is stereoselective only in the former case [33-35].

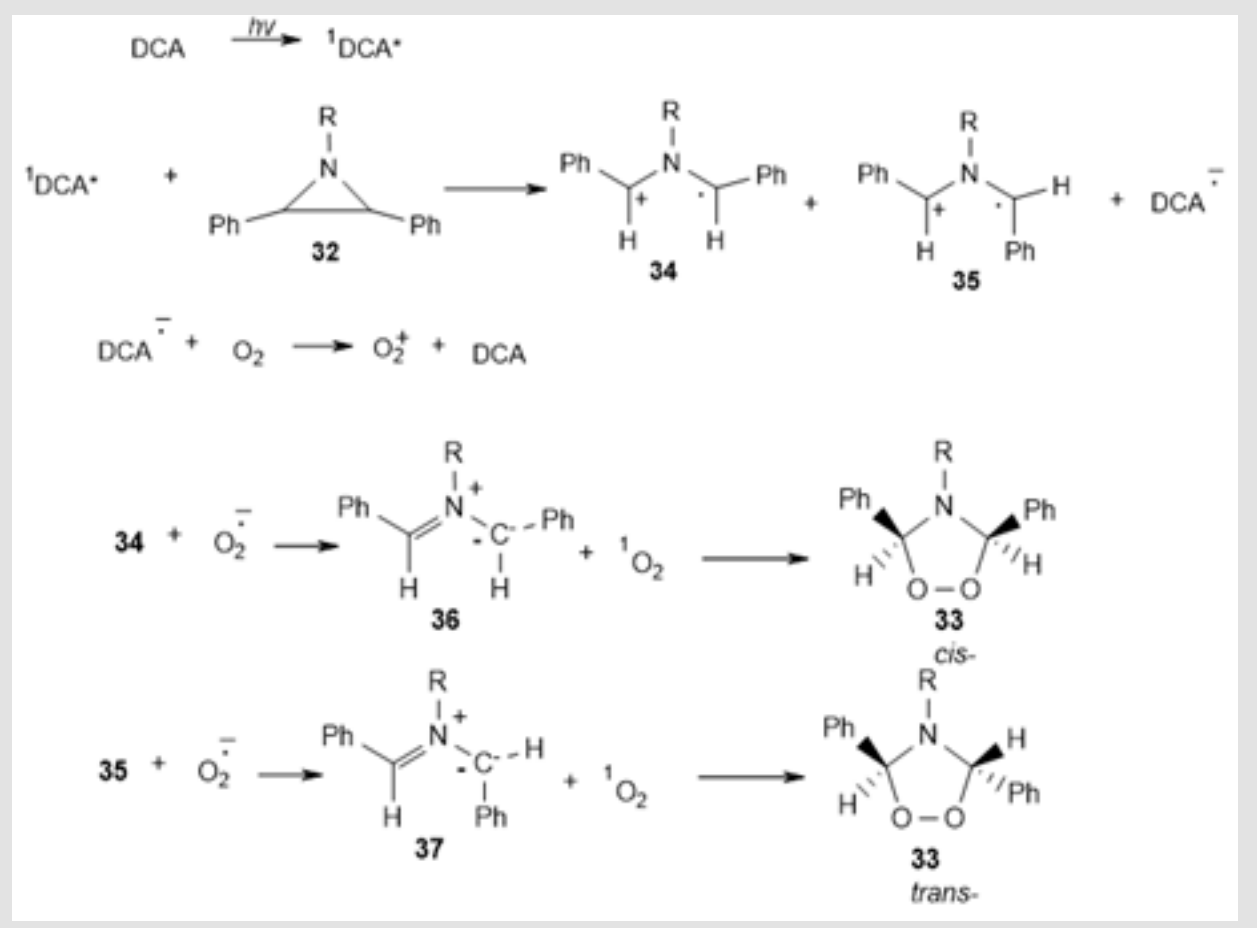

Scheme 14: Proposed mechanism involving addition of singlet oxygen to intermediate azomethine ylides. 
An example of photochemical synthesis of (Z)-(4-benzyl5-methyl-1,2,4-dioxazolidin-3-yl) acrylonitrile 39 in 24\% yield by irradiation of cis-methylaziridine in acetonitrile has been reported (Scheme 15) [36]. The visible light irradiation of the alkaloid derivative 13-oxidoberberine 40 in the presence of Bengal Rose dye afforded amino-peroxide 41 in $42 \%$ yield [37]
(Scheme 16). Y. Tamura and co-workers used photooxidation of 5-methoxy-1-methyl-6- phenylpyridin-3-oate 42 to perform a similar transformation giving 1,3-dipolar cycloadduct 43 (Scheme 17) [38]. 4-Hydroxy-1,2,4-dioxazolidine 45 was formed only as an intermediate in the photooxidation of $\mathrm{N}$-methylnitrone 44 (Scheme 18) [21].

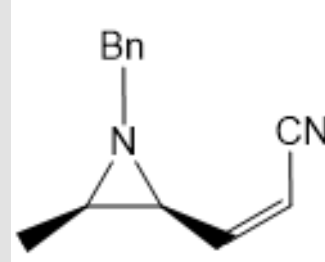

38

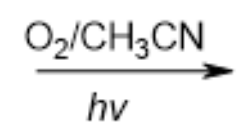

Scheme 15: Reactions of aziridines with molecular oxygen.<smiles>COc1ccc2c([O-])c3[n+](cc2c1OC)CCc1cc2c(cc1-3)OCO2</smiles><smiles>[CH]C1C(=O)C2C(OC)=C(OC)C1OC1(O)c3cc4c(cc3CCN21)OCO4</smiles>

Scheme 16: Photo-oxygenation of phenolic betaines.<smiles></smiles><smiles></smiles>

42

43

Scheme 17: Photooxygenation of 5-methoxy-1-methyl-6-phenylpyridinium-3-olate.<smiles>[R]C([Al])=[N+](C)[O-]</smiles>

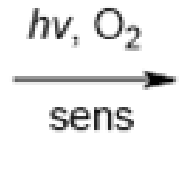<smiles>[R]C([Al])(O[O-])[N+](C)=O</smiles><smiles>[R]C(Br)(OO)[NH+](C)[O-]</smiles><smiles>[R]C1([Al])OCN(O)C1([R])[Na]</smiles>

Scheme 18: Photooxygenation of nitrones. 
Miscellaneous Methods for the Preparation of FiveMembered Aza-Peroxides

The ozonation and photooxidation of appropriate unsaturated compounds are the major methods for the preparation of the 1,2,4-dioxazolidine moiety. However, an amino-peroxide moiety can also be generated using some other approaches. A simple method for the synthesis of 1,2,4-dioxazolidines 46-50 in moderate yields is the Mannich reaction of alicyclic ketone with hydrogen peroxide and ammonia (Scheme 19) [39].<smiles>CCC(C)C(C)=O</smiles><smiles>O=C1CCCC1</smiles><smiles>O=C1CCCCC1</smiles><smiles>CC1CCCC(=O)C1</smiles><smiles>CC1CC(=O)CC(C)(C)C1</smiles><smiles>CC1=CC(=O)CC(C)(C)C1</smiles>

Scheme 19: Aminoperoxides from carbonyl compounds.

A synthetic route to 1,2,4-dioxazolidines 52a-c (formed in $60-80 \%$ yield) via oxidation of imines $51 \mathrm{a}-\mathrm{c}$ in a petroleum etherbenzene solution with air oxygen at -15 to $-20^{\circ} \mathrm{C}$ was discussed (Scheme 20) [40]. 1,1'-Peroxycyclohexylamine 53, which is a key intermediate in the production of Nylon-6 polymer [41], was also prepared by treatment of cyclohexanone with $\mathrm{H} 2 \mathrm{O} 2$ in the presence of $\mathrm{NH}_{4} \mathrm{Cl} / \mathrm{NH}_{4} \mathrm{OH}$ and $\mathrm{Na}_{2}$ EDTA followed by treatment with $\mathrm{NH}_{3}$ (Scheme 21) [42]. Mention should be made of the only method for the synthesis of 1,2,4-dioxazolidine-3,5-dione 55, a promising compound for industrial application as an initiator of free radical polymerization [43]. The reaction comprised treatment of $\mathrm{N}$-methyliminodicarbonyl dichloride 54 with $\mathrm{H}_{2} \mathrm{O}_{2}$ under alkaline conditions (Scheme 22).

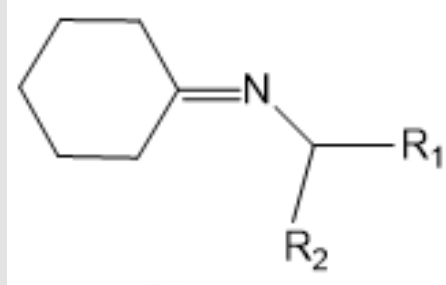

51 a-c

a $R_{1}=R_{2}=P h$

b $\mathrm{R}_{1}=\mathrm{R}_{2}=\mathrm{C}_{6} \mathrm{H}_{4} \mathrm{Cl}-\mathrm{p}$

c $\mathrm{R}_{1}=\mathrm{R}_{2}=\mathrm{C}_{6} \mathrm{H}_{4} \mathrm{CH}_{3}-\mathrm{p}$

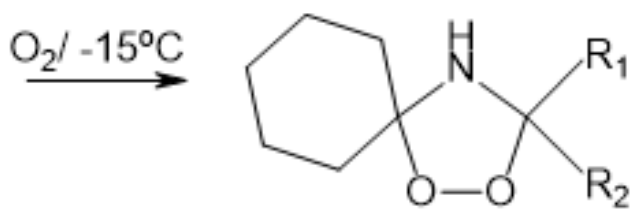

52 a-c

Scheme 20: Synthesis of 1,2,4-dioxazolidines.
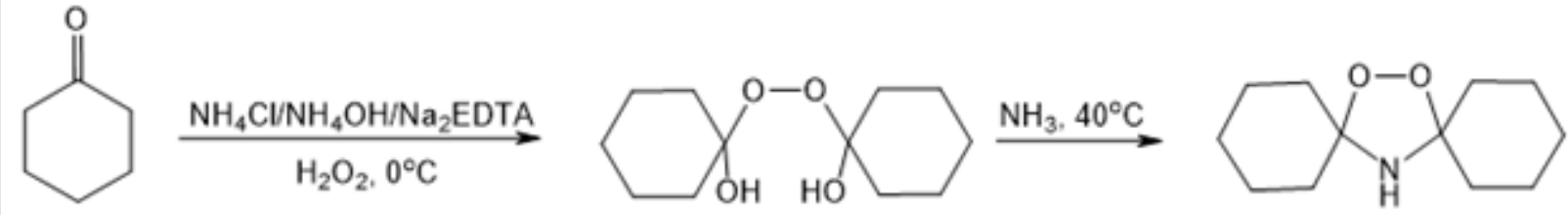

53

Scheme 21: Preparation of 1,1'-peroxycyclohexylamine. 


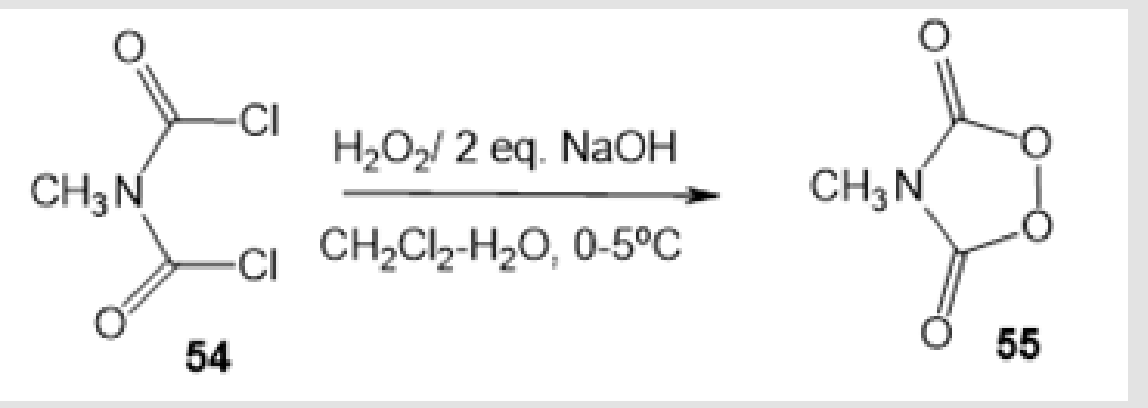

Scheme 22: Cyclic imidodiacyl peroxide.

\section{Six-Membered Amino-Peroxides}

A synthetic route to 1,2-dioxatetrahydropyridazines 58, 60 , and 61 [44] consisting in the reaction of compound 56 or 1,2-dialkylhydrazines 59 a,b with $\mathrm{CH}_{2} \mathrm{O}$ and $\mathrm{H}_{2} \mathrm{O}_{2}$ was proposed (Scheme 23). The authors suggested the intermediate formation of hydroperoxide 57. The six-membered amino-peroxides reported in the literature are mainly endoperoxides prepared by photooxidation of nitrogen-containing ketones. Indeed, photooxidation of pyrazin2-ones 62 with singlet oxygen in the presence of Methylene Blue dye gave rise to epidioxypyrazin-2-ones 63 with a six-membered amino-peroxide ring in the molecule (Scheme 24) [45].<smiles>CN[N+]1=Cc2ccccc2CC1</smiles>

56<smiles>CNN1CCc2ccccc2C1OO</smiles><smiles>CCCCCCC</smiles><smiles></smiles><smiles>[R]N1COOCN1[R]</smiles>

$60 \mathrm{R}=\mathrm{CH}_{3}$ $61 \mathrm{R}=\mathrm{C}_{2} \mathrm{H}_{5}$

Scheme 23: Synthesis 4,5-dioxa-tetrahydropyridazines.<smiles>[R]c1nc([R])c(=O)n([R])c1[R]</smiles>

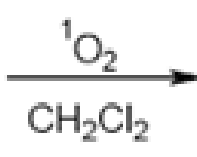

62<smiles>[R]C1=NC2([R])OOC1([R])C(=O)N2[R]</smiles>

63
a $\mathrm{R}=\mathrm{Me}, \mathrm{R}^{1}=\mathrm{Ph}, \mathrm{R}^{2}=\mathrm{Me}, 12 \%$
b $R=M e, R^{1}=P h, R^{2}=E t, 10 \%$
c $\mathrm{R}=\mathrm{Me}, \mathrm{R}^{1}=\mathrm{Ph}, \mathrm{R}^{2}=\mathrm{Pr}^{\mathrm{i}}, 9 \%$
d $R=M e, R^{1}=P h, R^{2}=P h, 10 \%$

Scheme 24: Photochemical reactions of the pyrazine-2-ones under an oxygen atmosphere. 
Irradiation of a solution of N-benzyl-2-pyridinones 64 in dichloromethane with a Na-lamp (940 W) in the presence of a catalytic amount of Tetraphenylporphin (TPP) in an oxygen atmosphere at $-78^{\circ} \mathrm{C}$ for $2 \mathrm{~h}$ yielded exclusively 1,4-endoperoxides 65 (Scheme 25) [46].

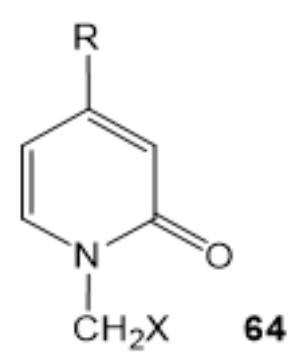

$$
\underset{\text { TPP }}{\stackrel{1}{\mathrm{O}_{2}, \mathrm{CH}_{2} \mathrm{Cl}_{2}}}
$$

64

a $\mathrm{R}=\mathrm{H}, \mathrm{X}=\mathrm{C}_{6} \mathrm{H}_{5}$

b $\mathrm{R}=\mathrm{H}, \mathrm{X}=p-\left(\mathrm{C}_{6} \mathrm{H}_{5}\right) \mathrm{C}_{6} \mathrm{H}_{4^{-}}$

c $\mathrm{R}=\mathrm{Me}, \mathrm{X}=p-\left(\mathrm{C}_{6} \mathrm{H}_{5}\right) \mathrm{C}_{6} \mathrm{H}_{4^{-}}$

d $\mathrm{R}=\mathrm{H}, \mathrm{X}=-\mathrm{CO}_{2} t-\mathrm{Bu}$

e $\mathrm{R}=\mathrm{Me}, \mathrm{X}=-\mathrm{CO}_{2} t-\mathrm{Bu}$

Scheme 25: Formation of endoperoxides by singlet oxygen addition.

The oxidation of alkadienone 66 at $0^{\circ} \mathrm{C}$ catalyzed by boron trifluoride etherate gave an intermediate betaine complex with Lewis acid 67, which rearranged on further oxidation to a mixture of diastereomeric endoperoxides 68 and 69 in a total yield of $72 \%$ (Scheme 26) [47]. The ozonolysis of vinyl ethers 70 in the presence of $\alpha$-phenyl-N-benzylnitrone afforded six-membered peroxides, 5-benzyl-6-phenyl-3-(1-phenylcycloalkyl)-5,6-dihydro-1,2,4,5trioxazines 71, in 79-95\% yields (Scheme 27) [48]. The cycloaddition of 2,2'-azodipyridine 72 to diphenyl ketene 73 , obtained in situ, followed by self-oxidation of intermediate 1,2-diazetidinone 74 furnished target dihydro-5,5-diphenyl-3,4-bis(2-pyridyl)-1,2,3,4dioxadiazin-6-one 75 (Scheme 28) [49].<smiles>C=C(CCCN)C(=O)/C(C)=C/c1ccccc1</smiles><smiles>CCOC(C)(C)C(=O)OC</smiles><smiles>CC1=C(OC(C)(C)C)[N+]2=C(CCC2)CC1c1ccccc1</smiles>

67
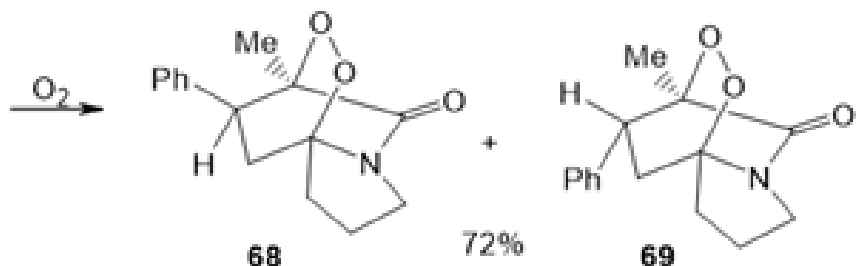

Scheme 26: Azide trapping and peroxide formation.

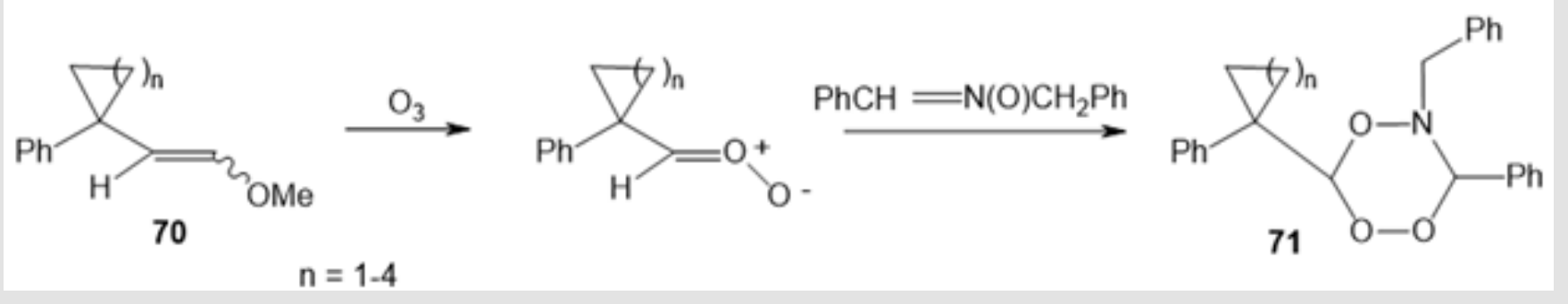

Scheme 27: Treatment of the vinyl ethers with ozone in the presence of a-phenyl-N-benzylnitrone. 


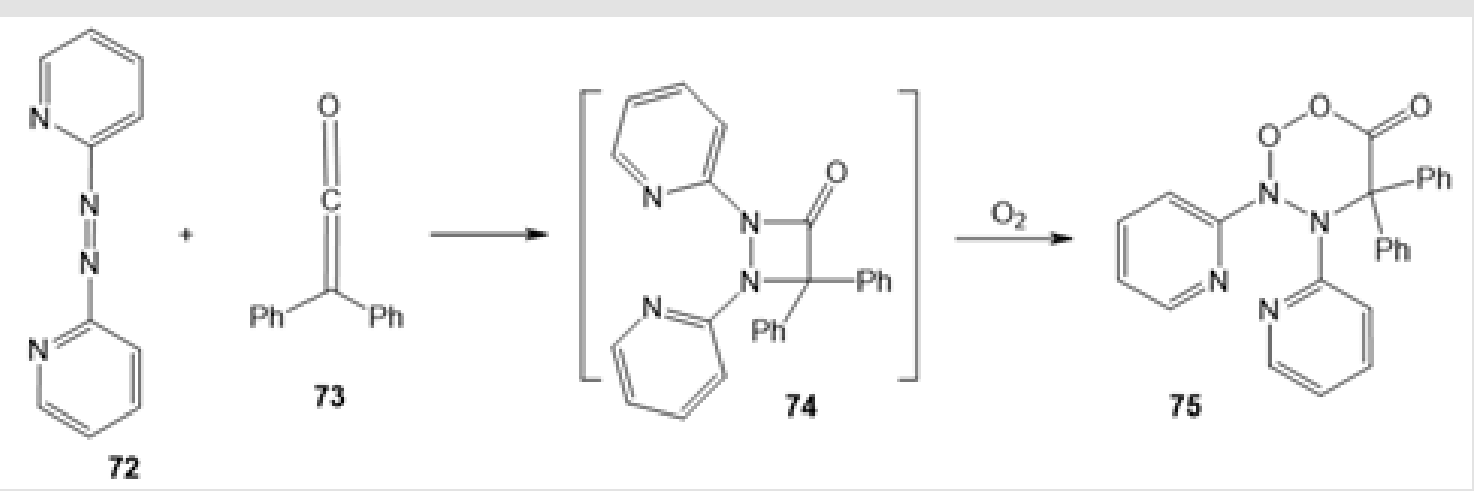

Scheme 28: Autooxidation of the 1,2-azetidinone.

\section{Eight-Membered Aza-Peroxides}

Ozonolysis of acenapthylene 76 in the presence of nitrones $77 \mathrm{a}-\mathrm{c}$ is an efficient route to polycyclic amino-peroxides $80 \mathrm{a}-\mathrm{c}$ containing the dihydro-1,2,5,7,4-tetraoxazocine ring. The reaction proceeds as the $[3+3+2]$-cycloaddition between the carbonyl oxide moiety, nitrone, and aldehyde group via intermediates 78 and 79 (Scheme 29) [50]. The yields of eight-membered amino-peroxides $80 \mathrm{a}-\mathrm{c}$ are 11,30 , and $45 \%$, respectively (Figure 1 ).

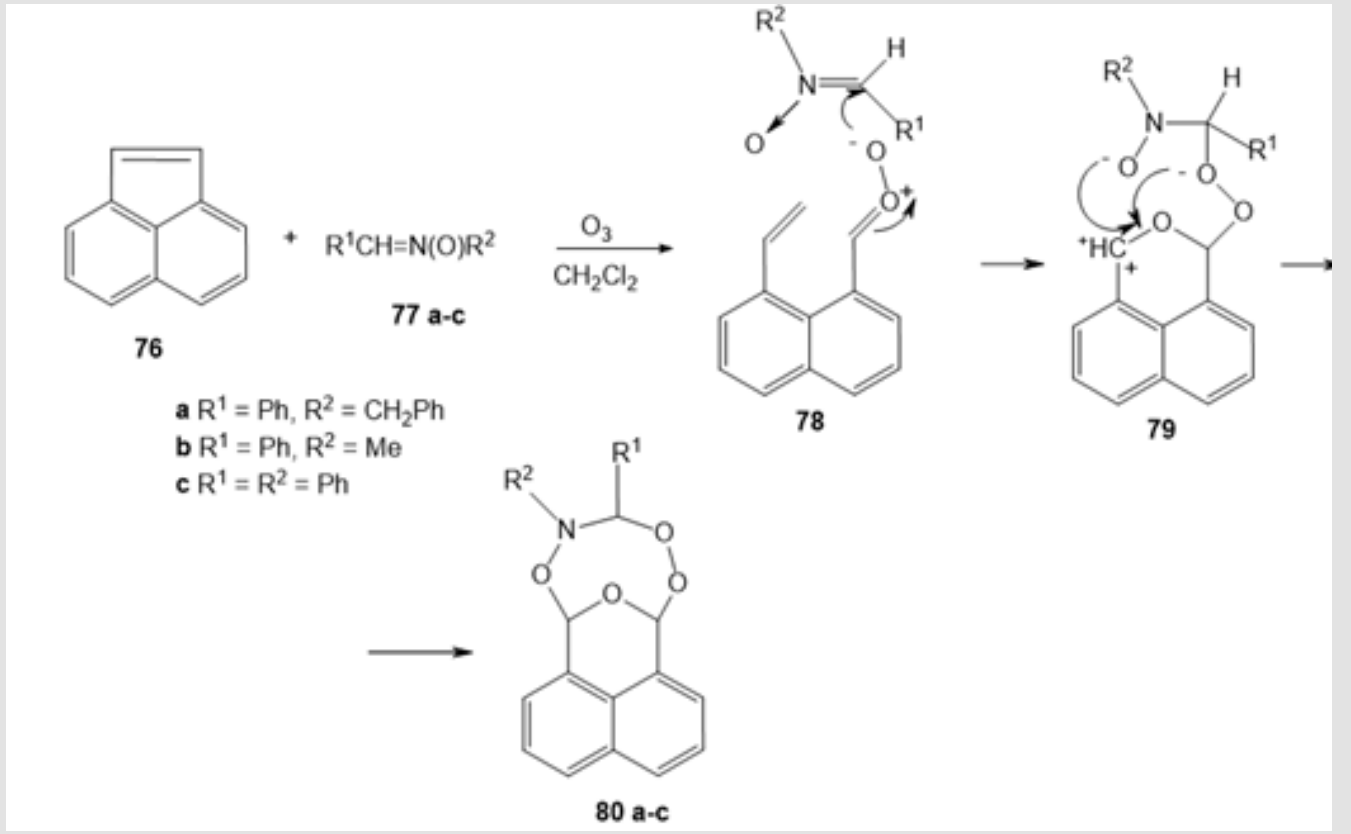

Scheme 29: The formation of the nitrone-incorporated cyclic peroxides.

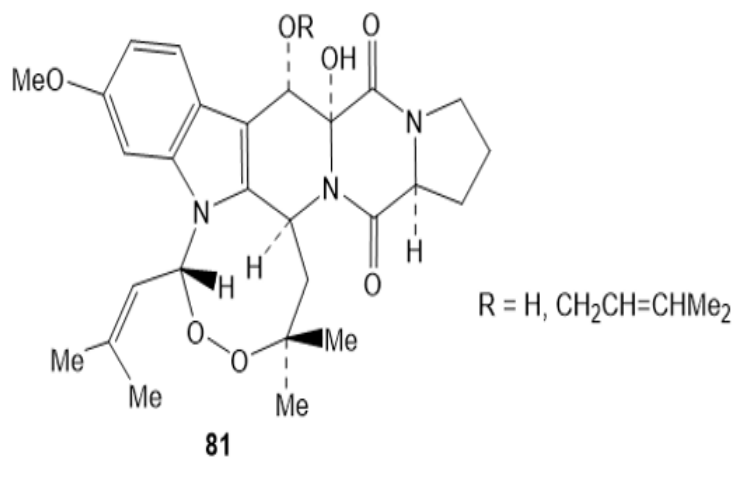

Figure 1.
An eight-membered cyclic amino-peroxide moiety is present in Verruculogen 81, a metabolite of Penicillium verrucutosum [51], and in the mycotoxins of several strains: Aspergillus caepitosus [52], A. fumigatus [53], A. fisheri [54], Penicillum piscarium [55], P. paxilli [56], P. estinogenum [57], P. simplicissmum, P. piceum, $P$. nigricans, P. raistricki [58], Eupenicillium sp. [59], and Neosartorya fischeri [60]. A $\mathrm{Sm}\left(\mathrm{NO}_{3}\right)_{3} \cdot 6 \mathrm{H}_{2} \mathrm{O}$-catalyzed process was developed for the synthesis of $\mathrm{N}$-substituted tetraoxazaspiroalkanes by ring transformation of pentaoxaspiroalkanes with primary amines at room temperature in THF [61]. Aryl- 87a-l and hetaryl-amines $87 \mathrm{~m}$ o undergo the ring transformation reaction to give $\mathrm{N}$-aryl(hetaryl)tetraoxazaspiroalkanes in 70-99\% yields (Scheme 30). 
<smiles>N[14CH2]OCOOC12CCCCC1OOCO2</smiles>

82-85

\section{$\left[\mathrm{Sm}\left(\mathrm{NO}_{3}\right)_{3} \cdot 6 \mathrm{H}_{2} \mathrm{O}\right]$}

THF

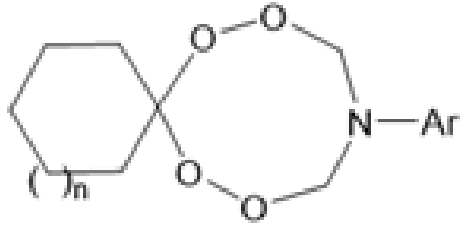

87 a-o, 88a, 89d, 90a, 91d, 92d

$\mathrm{n}=1, \quad \mathrm{Ar}=\mathrm{Ph}(\mathbf{8 7} \mathbf{a}), o-\mathrm{FC}_{6} \mathrm{H}_{4}(\mathbf{8 7 b}), m-\mathrm{FC}_{6} \mathrm{H}_{4}(\mathbf{8 7} \mathrm{c}), p-\mathrm{FC}_{6} \mathrm{H}_{4}(\mathbf{8 7 d}), o-\mathrm{ClC}_{6} \mathrm{H}_{4}(\mathbf{8 7 i})$,

$m-\mathrm{ClC}_{6} \mathrm{H}_{4}(\mathbf{8 7 f}), p-\mathrm{ClC}_{6} \mathrm{H}_{4}(\mathbf{8 7 g}), 0-\mathrm{BrC}_{6} \mathrm{H}_{4}(\mathbf{8 7 h}), m-\mathrm{BrC}_{6} \mathrm{H}_{4}(\mathbf{8 7 i}), p-\mathrm{BrC}_{6} \mathrm{H}_{4}(\mathbf{8 7 j})$,

$o-\mathrm{CH}_{3} \mathrm{C}_{6} \mathrm{H}_{4}(87 \mathrm{k}), m-\mathrm{CH}_{3} \mathrm{C}_{6} \mathrm{H}_{4}$ (87I), 2-Py (87m),3-Py (87n), 4-Py (87o)

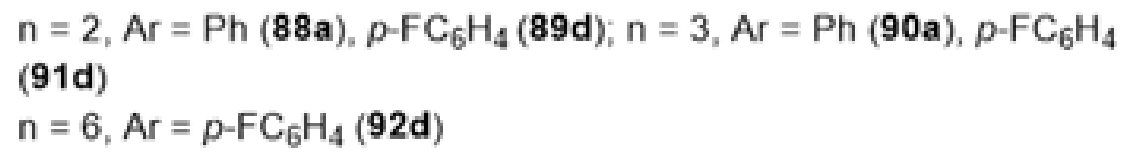

Scheme 30: Synthesis of N-substituted tetraoxazaspiroalkanes.

The yield of amino-peroxides depends little on the structure of the starting monomers and reagents, which made it possible to perform the $\mathrm{Sm}\left(\mathrm{NO}_{3}\right)_{3} \cdot 6 \mathrm{H}_{2} \mathrm{O}$-catalyzed reaction for primary amines and pentaoxacanes, resulting in the selective formation of 3,3-dialkyl-7-(o,m,p-halophenyl)-1,2,4,5,7-tetraoxazocanes 96b-d, 97i-g, 98b,f,g in 75-90\% yields (Scheme 31) [62]. Spiro\{ad- amantane-[2,3']- $\left(1^{\prime}, 2^{\prime}, 4^{\prime}, 5^{\prime}, 7^{\prime}\right.$-pentaoxacane $\left.)\right\} 99$ reacts with aryl(o,p-fluorophenyl, m,p-chlorophenyl, o,p-methoxyphenyl, o,m,p-methylphenyl)amines in the presence of the $\mathrm{Sm}(\mathrm{NO}) 3 \cdot 6 \mathrm{H} 2 \mathrm{O}$ catalyst (5 mol. \%) ( 20oC, THF) to give $7^{\prime}$-arylspiro\{adaman-

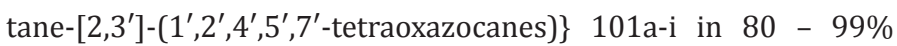
yields (Scheme 32) [63].<smiles>[R]C1([R])OOCOCOO1</smiles>

93-95

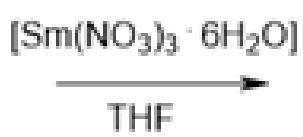

口

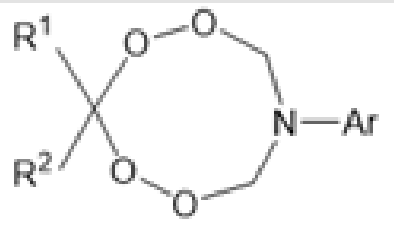

96 b-d, 97 i-g, 98 b,f,g
$\mathrm{R}^{1}=\mathrm{Et}, \mathrm{R}^{2}=\mathrm{Bu}(\mathbf{9 3})$

$\mathrm{R}^{1}=\mathrm{R}^{2}=\mathrm{Bu}(\mathbf{9 4})$

$\mathrm{R}^{1}=\mathrm{C}_{6} \mathrm{H}_{13}, \mathrm{R}^{2}=\mathrm{Me}(\mathbf{9 5})$
$\mathrm{R}^{1}=\mathrm{Et}_{1} \mathrm{R}^{2}=\mathrm{Bu}, \mathrm{Ar}=0-\mathrm{FC}_{6} \mathrm{H}_{4}(\mathbf{9 6} \mathrm{b}), m-\mathrm{FC}_{6} \mathrm{H}_{4}(\mathbf{9 6} \mathrm{c}), p-\mathrm{FC}_{6} \mathrm{H}_{4}(\mathbf{9 6 \mathrm { d }})$,

$\mathrm{R}^{1}=\mathrm{R}^{2}=\mathrm{Bu}, \mathrm{Ar}=0-\mathrm{ClC}_{6} \mathrm{H}_{4}(\mathbf{9 7} \mathrm{i}), m-\mathrm{ClC}_{6} \mathrm{H}_{4}(\mathbf{9 7 f}), p-\mathrm{ClC}_{6} \mathrm{H}_{4}(\mathbf{9 7} \mathbf{g})$,

$\mathrm{R}^{1}=\mathrm{C}_{6} \mathrm{H}_{13}, \mathrm{R}^{2}=\mathrm{Me}, \mathrm{Ar}=o-\mathrm{FC}_{6} \mathrm{H}_{4}(98 \mathrm{~b}), m-\mathrm{ClC}_{6} \mathrm{H}_{4}(\mathbf{9 8 f}), p-\mathrm{ClC}_{6} \mathrm{H}_{4}(\mathbf{9 8 g})$

Scheme 31: Ring transformation of pentaoxakanes.

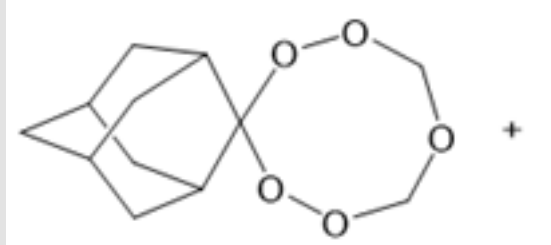

99
[Sm]<smiles>N[Al]</smiles>
100 a-i

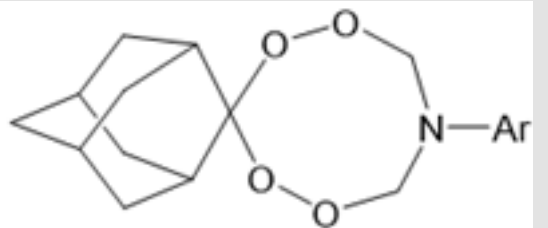

101 a-i

$\mathrm{Ar}=o-\mathrm{FC}_{6} \mathrm{H}_{4}(\mathbf{a}), p-\mathrm{FC}_{6} \mathrm{H}_{4}(\mathbf{b}), m-\mathrm{ClC}_{6} \mathrm{H}_{4}(\mathbf{c}), p-\mathrm{ClC}_{6} \mathrm{H}_{4}(\mathbf{d}), o-\mathrm{CH}_{3} \mathrm{C}_{6} \mathrm{H}_{4}(\mathbf{e}), m-\mathrm{CH}_{3} \mathrm{C}_{6} \mathrm{H}_{4}(\mathbf{f})$, $p-\mathrm{CH}_{3} \mathrm{C}_{6} \mathrm{H}_{4}(\mathbf{g}), o-\mathrm{CH}_{3} \mathrm{OC}_{6} \mathrm{H}_{4}(\mathbf{h}), p-\mathrm{CH}_{3} \mathrm{OC}_{6} \mathrm{H}_{4}$ (i)

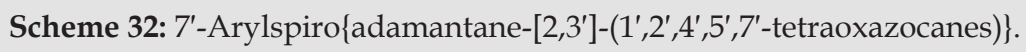


Apart from arylamines, aromatic diamines (o,m,pphenylenediamines) were also reacted with spiro\{adamantane$\left[2,3^{\prime}\right]-\left(1^{\prime}, 2^{\prime}, 4^{\prime}, 5^{\prime}, 7^{\prime}\right.$-pentaoxacane $\left.)\right\}$ 99. The ring transformation of compound 99 involving p-phenylenediamine 102 (5 mol.\% of $\left.\mathrm{Sm}\left(\mathrm{NO}_{3}\right)_{3} \cdot 6 \mathrm{H}_{2} \mathrm{O}, 20^{\circ} \mathrm{C}, 6 \mathrm{~h}, \mathrm{THF}\right)$ also yielded the target 4-spiro[adamantane-2,3'- $\left[1^{\prime}, 2^{\prime}, 4^{\prime}, 5^{\prime}, 7^{\prime}\right]$ tetraoxazacane]-7'-yl) aniline 103, whereas the reaction with m-phenylenediamine produced a precipitate insoluble in organic solvents.

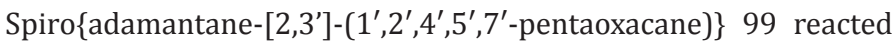
with o-phenylenediamine 104 to give adamantanone 106 and 2H,5H-1,6-(methanedioximethano)benzo[e][1,2,4,7]-dioxazocine 105 (Scheme 33) [63].

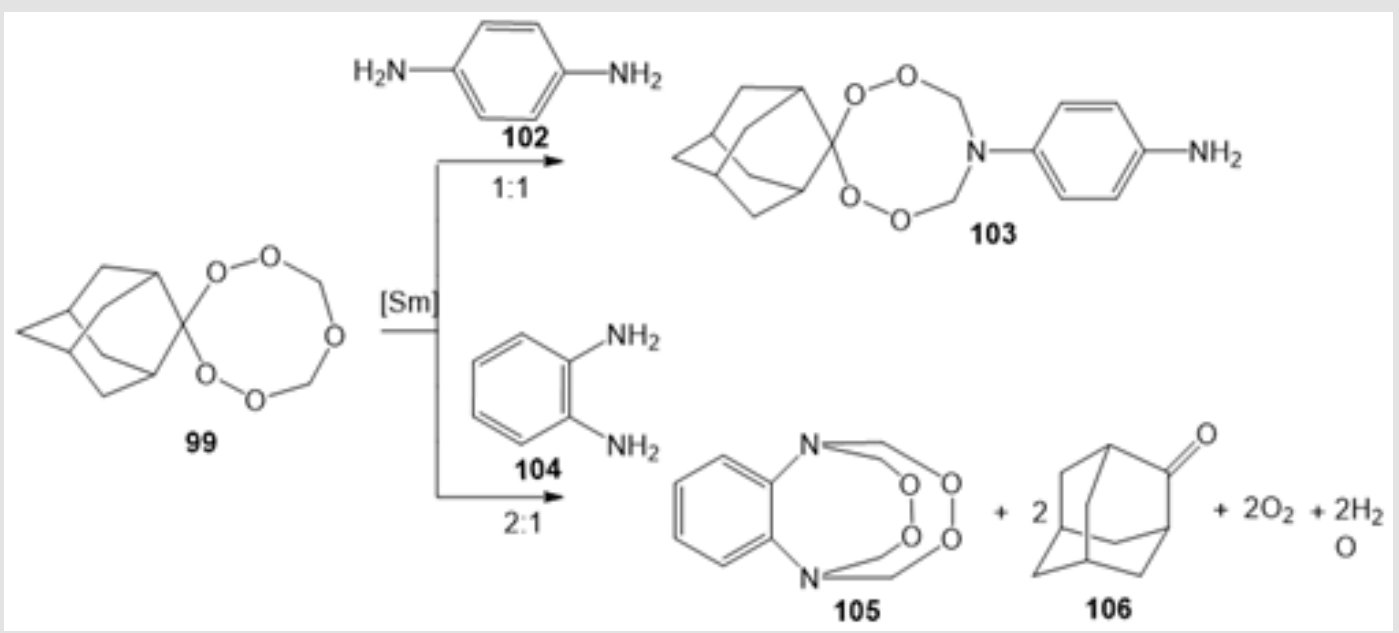

Scheme 33: Ring transformation of spiro $\left\{\right.$ adamantane- $\left[2,3^{\prime}\right]-\left(1^{\prime}, 2^{\prime}, 4^{\prime}, 5^{\prime}, 7^{\prime}\right.$-pentaoxacane $\left.)\right\}$ with aromatic diamines.

\section{Acyclic Amino-Peroxides}

There are few published cases of preparation of alicyclic amino-peroxides 108 and 110 by oxidative peroxyformylation of methylaminobenzene 107 and piperidine 109 (Scheme 34) $[64,65]$. Treatment of cyclohexanone with ammonia and tert- butyl hydroperoxide produces 1-tert-butylperoxycyclohexylamine 111 (Scheme 35) [66]. Whereas cyclic amino-peroxides are synthesized by oxidative transformations, the peroxides with a side-chain nitrogen atom are prepared via non-oxidative reactions. The most widely used method is the Rieche version of the Mannich formylation. In this case, tert-butyl hydroperoxide acts as a very potent nucleophile. J. Vennerstrom and co-workers used this protocol to synthesize tert-butylamino-peroxides 112-116 [67]. Amines were selected in such a way that the target amino-peroxides had endocyclic, exocyclic, and aliphatic or aromatic nitrogen atom. Amino-peroxides 112-116 showed a higher activity in vitro towards Plasmodium falciparum than artemisinin (Scheme 36).<smiles>CNc1ccccc1</smiles>

107

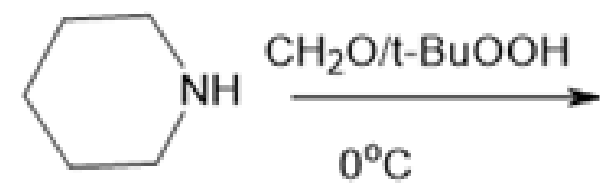

109<smiles>CN(COOCN(C)c1ccccc1)c1ccccc1</smiles>

$83 \%$

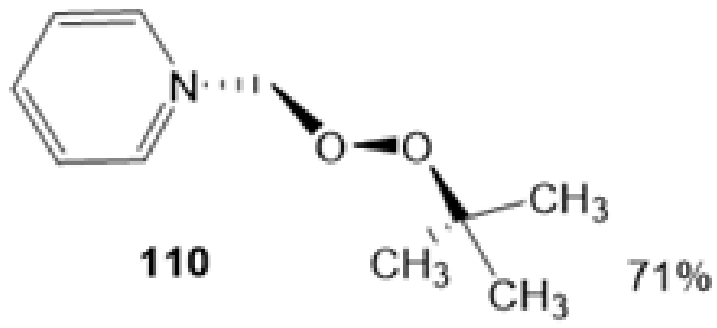

Scheme 34: Alicyclic amino-peroxides. 


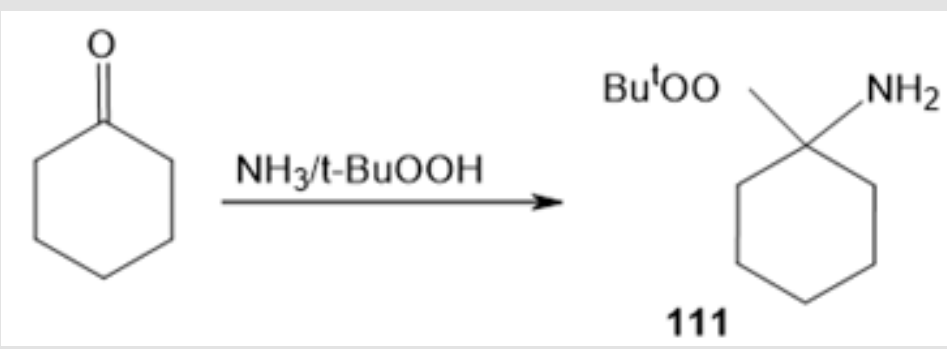

Scheme 35: Synthesis of 1-tert-butylperoxycyclohexylamine.

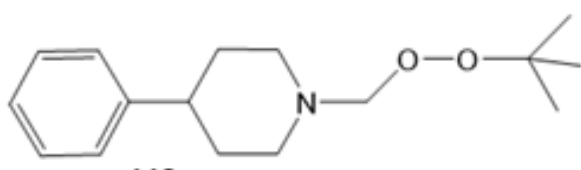

112

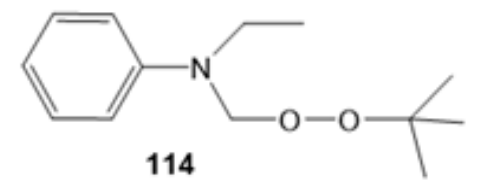

114

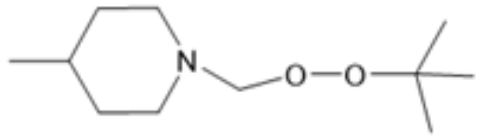

115

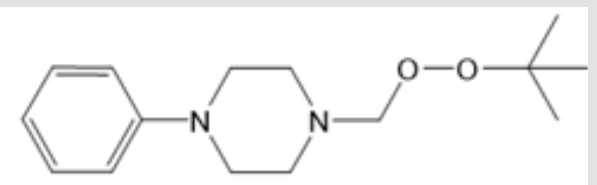

113

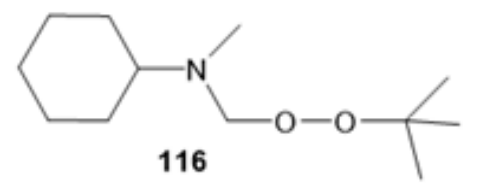

Scheme 36: Structure of aminoperoxides.

In 2001, N. Sundar and co-workers used a similar reaction to prepare tert-butyl peroxyamines 118-128, which were tested for antimalarial properties against the P. berghei and P. falciparum strains of malaria (Scheme 37) [68]. Acyclic diaminodiperoxides were prepared by the reaction of 1,1-bis(hydroperoxy)cycloalkanes with formaldehyde and primary arylamines catalyzed by Sm compounds $\left(\mathrm{SmCl}_{3} \cdot 6 \mathrm{H}_{2} \mathrm{O}, \mathrm{Sm}\left(\mathrm{NO}_{3}\right)_{3} \cdot 6 \mathrm{H}_{2} \mathrm{O}, \mathrm{SmCl}_{3} / \gamma-\mathrm{Al}_{2} \mathrm{O}_{3}, \mathrm{Sm}\left(\mathrm{NO}_{3}\right)_{3} / \gamma^{-}\right.$ $\mathrm{Al}_{2} \mathrm{O}_{3}$ ) [62]. The reactions of ortho-aryl(chlorophenyl, fluorophe- nyl)amines 129a,d with formaldehyde and 1,1-bis(hydroperoxy) cycloalkanes 130, 83, and 84 afford acyclic 1,1-bis[N-(peroxymethyl)-N-arylamino]cycloalkanes (131-133)a,d in 63-75\% yields. The replacement of ortho-arylamines $129 \mathrm{a}$,d by meta-aryl(chlorophenyl, fluorophenyl)amines $129 \mathrm{c}$,d results in the formation of a mixture of acyclic (134-136)c,d and cyclic (137-139)c,d amino-peroxides in $1: 1$ ratio (Scheme 38).

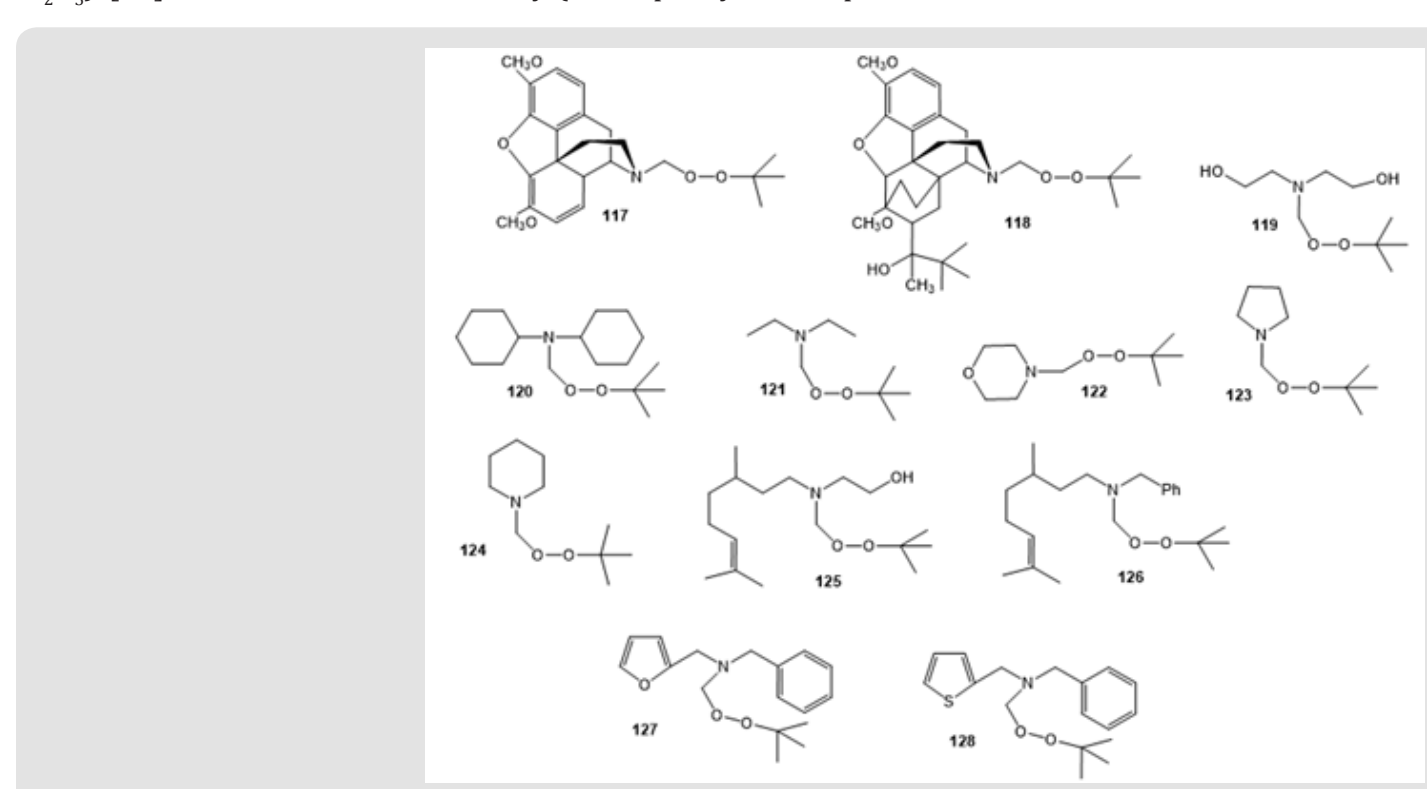

Scheme 37: Aminoperoxides as potential antimalarias. 


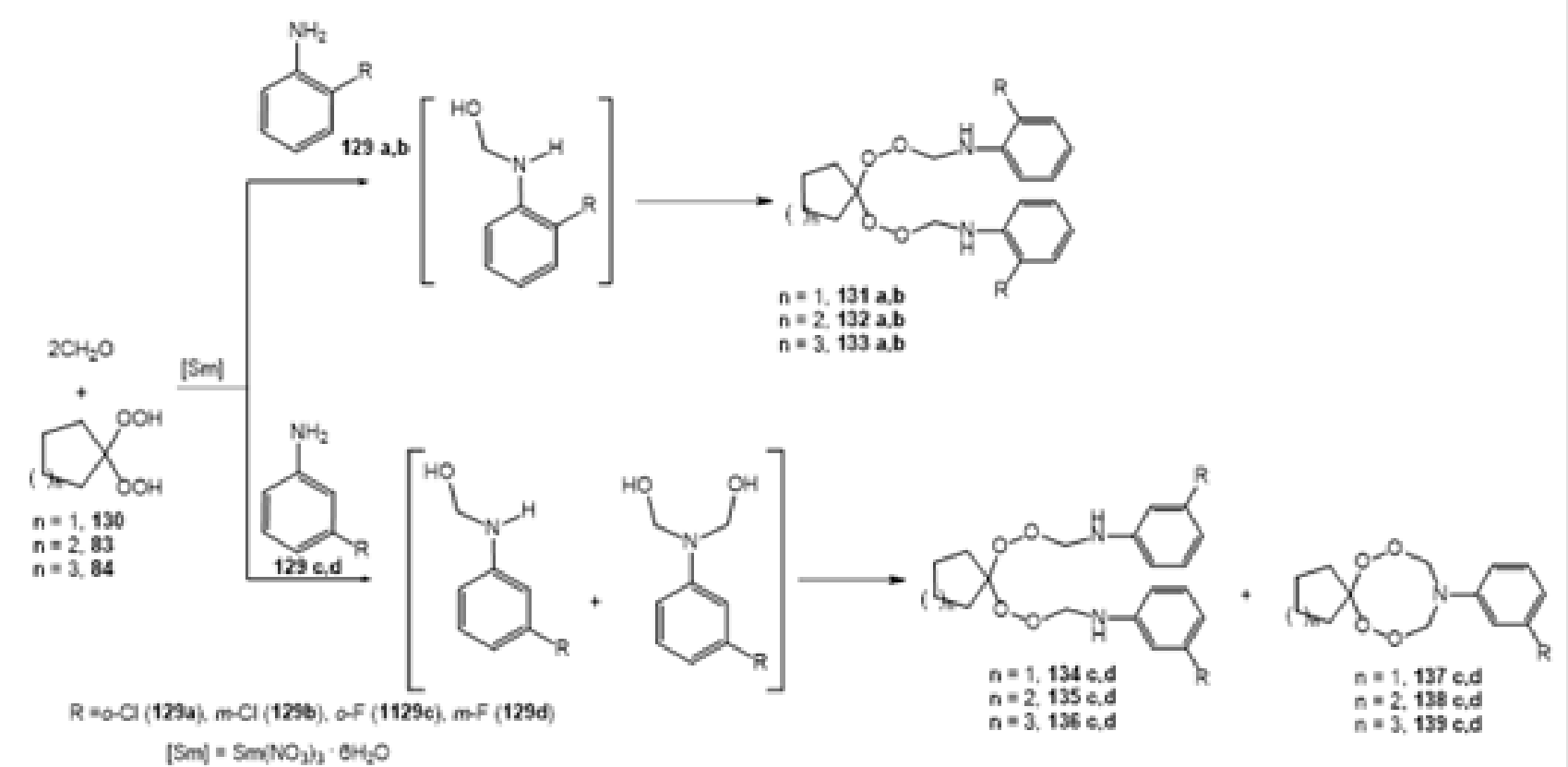

Scheme 38: Cyclic and acyclic Aminodiperoxides.

\section{Conclusion}

Analysis of the literature demonstrates that the recend advances in the synthesis of organic amino-peroxides have been stimulated by their practical use, first of all, with the prospects for development of efficient medicinal drugs based on these compounds. Relatively low degree of exploration of aminoperoxides is caused by the lack of efficient methods for their synthesis. Today, photochemical ozonolytic oxidation of nitrogencontaining compounds is the method of choice for the synthesis of cyclic amino-peroxides. This method provided considerable progress in the synthesis of five-membered 1,2,4-dioxazolidine derivatives. The successful development of catalytic methods for the synthesis of aza-diperoxides in recent years is noteworthy. Of particular interest and practical value are recent studies on the synthesis of amino-diperoxides by one-pot ring transformation of pentaoxaspiroalkanes to tetraoxazaspiroalkanes on treatment with primary amines and by cyclocondensation of 1,1-bis(hydroperoxy) cycloalkanes with formaldehyde and primary amines catalyzed by lanthanide salts and complexes.

\section{Acknowledgement}

This work was financially supported by the Russian Science Foundation (RSF projects 18-73-00014).

\section{References}

1. Baeyer A, Villiger V (1990) On the nomenclature of superoxides and superoxides of aldehydes. Chem Ber 33: 2479-2487.

2. Harder T, Wessig P, Bendig J, Stosser R (1999) Photochemical reactions of nitroso oxides at low temperatures: The first experimental evidence for dioxaziridines. J Am Chem Soc 121: 6580-6588.
3. Ishikawa S, Nojima T, Sawaki Y (1996) Reactivity of nitroso oxides: Effect of polar substituents and reaction mechanism J Chem Soc Perkin Trans 1: 127-132.

4. Zelentsova NV (2004) Peroxides at the beginning of the third millennium: Synthesis, properties, and application. Nova Science Publishers, New York, pp. 239-251

5. Safiullin RL, Khursan SL, Chainikova EM, Danilov VT (2004) Formation of nitroso oxides in the photolysis of aromatic azides: Analysis of products; reaction kinetics and mechanism. Kinetics and Catalysis 45: 640-648.

6. Zelentsov SV, Zelentsova NV, Shchepalov AA (2002) Nitrene adducts with oxygen in the photooxidation reactions of organic azides. High Energ Chemi 36: 326-332.

7. Srinivasan A, Kebede N, Saavedra JE, Nikolaitchik AV, Brady DA, et al. (2001) J Am Chem Soc 123: 5465-5472.

8. Makareeva EN, Lozovskaya EL, Zelentsov SV (2001) Chemiluminescence upon photooxidation of 4,4"-diazidodiphenyl with molecular oxygen. High Energ Chem 35: 177-180.

9. Ishikawa S, Tsuji S, Sawaki YJ (1991) Am Chem Soc 113: 4282-4288.

10. Sawaki Y, Ishikawa S (1987) Reactivity of nitroso oxides: Oxygen transfer as an electrophilic peroxy radical. J Am Chem Soc 109: 584-586.

11. Adam W (1992) Organic peroxides. John Wiley \& Sons, pp. 221-254.

12. Adam W (2006) The chemistry of peroxides. John Wiley \& Sons, pp. 1171-1209.

13. Angelo Albini, Maurizio Fagnoni (2010) Handbook of synthetic photochemistry. John Wiley \& Sons, pp. 353-386.

14. Bengt G Ranby, Rabek JF (1978) Singlet oxygen: Reactions with organic compounds and polymers. Wiley, pp. 264.

15. George MV, Bhat V (1979) Photooxygenations of nitrogen heterocycles. Chem Rev 79: 447-478.

16. Wamser CC, Herring JW (1976) Photooxidation of benzophenone oxime and derivatives. J Org Chem 41: 1476-1477. 
17. Ocal N, Yano LM, Erden I (2003) Photooxygenation of the CN bond: A mild new method for oxidative CC cleavage. Tetrahedron Lett 44: 69476949.

18. Ocal N, Erden I (2001) Tetrahedron Lett 42: 4765-4767.

19. Kawamura Y, Takayama, R, Nishiuchi, M, Tsukayama M (2000) Curious oxygen effect on photosensitized electron-transfer reactions of benzophenone oxime 0-methyl ethers: One-way photoisomerization of an iminic double bond. Tetrahedron Lett 41: 8101-8106.

20. Kawamura Y, Abe T, Tsukayama M (2003) Int J Mod Phys B 17: 14871491.

21. White EH, Li M, Roswell DF (1991) The chemiluminescence of amides and monoacyl hydrazides based on firefly dehydroluciferin. Photochem Photobiol 53: 125-130.

22. Kraljic I, El Mohsni S (1978) A new method for the detection of singlet oxygen in aqueous solutions. Photochem Photobiol 28: 577-581.

23. Linetsky M, Ortwerth B (1996) Quantitation of the reactive oxygen species generated by the UVA irradiation of ascorbic acid-glycated lens proteins. Photochem Photobiol 63: 649-655

24. Wang A, Marino AR, Gasyna Z, Gasyna E, Norris J (2008) Photoprotection by porcine eumelanin against singlet oxygen production. Photochem. Photobiol 84: 679-682.

25. Ponder M, Fowler JE, SchaeferIII HF (1994) J Org Chem 59: 6431-6436.

26. McCullough KJ, Mori M, Tabuchi T, Yamakoshi H, Kusabayashi S, et al. (1995) [3 + 2] Cycloadditions of carbonyl oxides to imines: an alternative approach to the synthesis of 1,2,4-dioxazolidines. J Chem Soc Perkin Trans 1 1: 41-48.

27. Ushigoe Y, Satake S, Masuyama A, Nojima M, McCullough KJ (1997) Synthesis of 1,2,4-dioxazolidine derivatives by the ozonolysis ofindenes in the presence of primary amines. J Chem Soc Perkin Trans 1 13: 19391942.

28. Griesbaum K, Liu X, Henke H (1998) N-methoxy-1,2,4-dioxazolidines by ozonolysis reactions. J Org Chem 63: 1086-1089.

29. Lee KR, Lee SF, Huh TS (2000) Korean Chem Soc 21: 1039-1040.

30. Filina GG, Bortyan TA, Menyailo AT, Pospelov MV (1980) Formation of 3, 5-dioctyl-1, 2, 4-dioxazole in the ozonation of 1-decene in the presence of ammonia. J Org Chem 16(4): 782784.

31. Patrick JB, Witkop BJ (1954) Mechanism of oxidation. Xv. Conversion of benzoxazine hydroperoxides to the parent benzoxazines. J Org Chem 19: 1824-1829.

32. Kazakova OB, Kazakov DV, Yamansarov EY U, Medvedeva NI, Tolstikov GA, et al. (2011) Synthesis of triterpenoid-based 1,2,4-trioxolanes and 1,2,4-dioxazolidines by ozonolysis of allobetulin derivatives. Tetrahedron Lett 52: 976-979.

33. Schaap AP, Siddiqui S, Prasad G, Palomino E, Lopez L (1984) Cosensitized electron transfer photo-oxygenation: The photochemical preparation of 1,2,4-trioxolanes, 1,2-dioxolanes and 1,2,4-dioxazolidines. J Photochem 25: 167-181.

34. Schaap AP, Prasad G, Gagnon S (1983) Formation of a 1,2,4-dioxazolidine by electron-transfer photooxygenation of 1-butyl-2,3-diphenylaziridine. Tetrahedron Lett 24: 3047-3050.

35. Schaap A.P, Prasad G, Siddiqui S (1984) Tetrahedron Lett 25: 3035-3038

36. Ishii K, Sone T, Shigeyama T, Noji M, Sugiyama S (2006) Tetrahedron 62 10865-10878.

37. Kondo Y, Imai J, Inoue HJ (1980) Chem Soc Perkin Trans 17: 911-918.

38. Tamura Y, Akita M, Kiyokawa H, Cheu LC, Ishibashi H (1978) Tetrahedron Lett 19: 1751-1752.

39. Hawkins EG E (1969) Reactions of organic peroxides. Part X. amino peroxides from cyclohexanone. J Chem Soc C 20: 2663-2670.
40. Hawkins EG E (1971) Reactions of organic peroxides. Part XVI. amino peroxides from autoxidation of imines. J Chem Soc C 1: 160-166.

41. Hawkins EGE (1976) Peroxy compounds and processes for their preparation. US Patent 5: 532-587

42. Troger J, Weiberg 0, Weigert W (1976) Process for the production of 1,1'-peroxydicyclohexylamine. US Patent 5: 108-195.

43. Hagemann H, Angew (1981) Heterocyclic Chemistry. Chem Int Ed 20: 784.

44. Schmitz E, Liebigs Ann (1960) Cyclic peroxides from hydrazine compounds. willey 635: 73-82.

45. Nishio T, Tokunaga N, Kondo M, Omote YJ (1988) Chem Soc Perkin Trans 1(11): 2921-2925.

46. Matsumoto M, Yamada M, Watanabe, N (2005) Reversible 1,4-cycloaddition of singlet oxygen to N-substituted 2-pyridones: 1,4-endoperoxide as a versatile chemical source of singlet oxygen. Chem Commun 4: 483-485.

47. Rostami A, Wang Y, Arif AM, McDonald R (2007) Intramolecular azide trapping of the nazarov intermediate: Formation of peroxy-bridged indolizidinones via a deep-seated rearrangement and aerobic oxidation. West, FG Org lett 9: 703-706.

48. Fukagawa R, Nojima (1994) M J Chem Soc Perkin Trans1 17: 2449-2454.

49. Colonna, M Risaliti, A Grazz Chim (1960) 90: 1165.

50. Satake S, Ushigoe Y, Nojima M, McCullough KJ (1995) J Chem Soc Chem Commun 14: 1469-1470.

51. Cole RJ, Kirksey JW, Moore JH, Blankenship BR, Diner UL, et al. (1972) J Appl Microbiol 24: 248 - 250

52. Schroeder HW, Cole RJ, Hein H, Kirksey JW (1975) Tremorgenic mycotoxins from Aspergillus caespitosus. J Appl Microbiol 29(6): $857-$ 858.

53. Dorner JW, Cole RJ, Hill RA (1984) J Agric Food Chem 32: 411-413.

54. Patterson DSP, Shreeve BJ, Roberts BA, MacDonald SM (1981) Verruculogen produced by soil fungi in england and wales. Appl Environ Microbiol 42: 916-917.

55. Gallagher RT, Latch GCM (1977) Production of the tremorgenic mycotoxins verruculogen and fumitremorgin B by Penicillium piscarium Westling. Appl Environ Microbiol 33: 730-731.

56. Cockrum PA, Culvenor CCJ, Edgar JA Payne (1979) AL J Nat Prod 42: 534 536.

57. Day JB, Mantle PG, Show BI (1980) Gen Microbiol J 117: 405-410.

58. Day JB, Mantle PG (1982) Appl Environ Microbiol 43: 514-516

59. YHorie Y, Maebayashi, Yamazaki M, Maikotokishin (1985) Chem Abstr 105: 22-35.

60. Nelsen PV, Beuchat LR, Frisvad JC (1988) Appl Environ Microbiol 54: 1504-1510.

61. Makhmudiyarova NN, Khatmullina GM, Rakhimov RSh, Meshcheryakova ES, Ibragimov AG, et al. (2016) Tetrahedron 72: 3277-3281.

62. Makhmudiyarova NN, Rakhimov, RSh Tyumkina TV, Meshcheryakova ES, Ibragimov (2019) J Org Chem 5: 620-632.

63. Tyumkina TV, Makhmudiyarova NN, Kiyamutdinova GM, Meshcheryakova ES, Bikmukhametov, et al. (2018) UM Tetrahedron 74: 749-1758.

64. Horner L, Knapp KH (1960) Chem Abst 54: 1382c.

65. Rieche A, Schmitz E, Beyer E (1959) Chem Abst 53: № 17116b.

66. Hawkins EGE (1969) Reactions of organic peroxides. Part XIV. Aminoperoxides from carbonyl compounds, primary amines, and hydrogen peroxide or hydroperoxide. J Chem Soc C 20: 2682-2686. 
67. Vennerstrom JL (1989) J Med Chem 32: 64-68.

ISSN: 2574-1241

DOI: 10.26717/BJSTR.2019.21.003561

Nataliya N Makhmudiyarova. Biomed J Sci \& Tech Res

(C) This work is licensed under Creative

Submission Link: https://biomedres.us/submit-manuscript.php
68. Sundar N, Jacob VT, Bhat SV, Valecha N, Biswas S I (2001) Antimalarial t-Butylperoxyamines. Bioorg Med Chem Lett 11(17): 2269-2272.

$\begin{array}{ll}\text { BIOMEDICAL } & \text { Assets of Publishing with us } \\ \text { RESEARCHES } & \text { - Global archiving of articles } \\ & \text { - Immediate, unrestricted online access } \\ & \text { - Rigorous Peer Review Process } \\ \end{array}$

